\title{
Systemic coccidioidomycosis in a dog in Northeastern Brazil
}

\author{
Rodrigo Cruz Alves ${ }^{1^{*}}$ (D) Édipo Moreira Campos ${ }^{1}$ (i) Raquel Annes Fagundes Silva ${ }^{1}$ (i) \\ Samara Tereza Morais Batista ${ }^{1}$ (D) Rosileide dos Santos Carneiro ${ }^{1}$ (i) Daniel Ricardo Rissi ${ }^{2}$ (i) \\ Glauco José Nogueira de Galiza ${ }^{1}$ (D) Antônio Flávio Medeiros Dantas ${ }^{1}$ (D)
}

${ }^{1}$ Hospital Veterinário da Universidade Federal de Campina Grande, 58708-110, Patos, PB, Brasil. E-mail: rodrigo_cruz90@live.com. ${ }^{*}$ Corresponding author.

${ }^{2}$ Athens Veterinary Diagnostic Laboratory, Department of Pathology, University of Georgia College of Veterinary Medicine, Athens, Georgia, USA.

ABSTRACT: We described a case of systemic infection by Coccidioides sp. in a dog. An adult, mixed breed, free-ranging male dog presented with clinical signs that included apathy, cachexia, anorexia, limited mobility with sternal recumbency, bilateral mucopurulent ocular discharge, dyspnoea, pulmonary crepitation, erosive and nodular lesions on the skin, and swelling and stiffness of the left tibiotarsal joint. The dog was submitted to a postmortem examination. Grossly, there were multiple yellow to white nodules in various organs. Histologically, the lesions were characterized as pyogranulomatous inflammation associated with fungal spherules morphologically consistent with Coccidioides sp. The dog was concomitantly diagnosed with undifferentiated sarcoma affecting the skin, lymph nodes, liver, and testicles. The diagnosis of coccidioidomycosis was made based on the histologic changes associated with morphotintorial features and positive immunolabeling of organisms with anti-Coccidioides immunohistochemistry. This case demonstrated that Coccidioides sp. can infect dogs that inhabit urban centers in the semiarid region of Northeastern Brazil, likely due to exposure to dust from contaminated environments.

Key words: dog disease, Coccidioides sp., spherules, arthroconidia.

Coccidioidomicose sistêmica em um cão no Nordeste do Brasil

RESUMO: Descreve-se um caso de infecção sistêmica por Coccidioides em um cão. Um cão adulto, sem raça definida e errante, atendido com sinais clínicos que incluíram apatia, caquexia, anorexia, dificuldade de locomoção com decúbito esternal, secreção ocular bilateral mucopurulenta, dispneia, crepitação pulmonar, lesões erosivas e nodulares na pele, aumento de volume e rigidez na articulação tibiotársica do membro pélvico esquerdo. O cão foi submetido a um exame post-mortem. Macroscopicamente, haviam múltiplos nódulos amarelobrancacentos em vários órgãos. Histologicamente, as lesões foram caracterizadas por inflamação piogranulomatosa associada a esférulas fúngicas morfologicamente consistentes com Coccidioides sp. O cão foi diagnosticado concomitantemente com sarcoma indiferenciado afetando a pele, linfonodos, figado e testículos. O diagnóstico de coccidioidomicose foi realizado com base nas alterações histológicas associadas as características morfotintoriais e imunomarcação positiva dos organismos com anti-Coccidioides na imuno-histoquímica. Esse caso demonstra que Coccidioides sp. pode infectar cães que habitam centros urbanos no semiárido do Nordeste do Brasil, provavelmente devido à exposição a poeira de ambientes contaminados.

Palavras-chave: doença de cão, Coccidioides sp., esférulas, artroconídios.

\section{INTRODUCTION}

Coccidioidomycosis is an endemic mycosis prevalent in arid regions of southwestern United States, Mexico, and semiarid regions of Central and South America (FISHER et al., 2002; LUNA-ISAAC et al., 2014; ZACHARY, 2017). The disease affects humans and other species of domestic and wild animals, and is caused by two species of dimorphic fungi, Coccidioides immitis and $C$. posadasii, which are found in the soil (GREENE, 2015; BOSCO et al.,
2016). Inhalation of arthroconidia constitutes the main route of infection in susceptible hosts (CASWELL \& WILLIAMS, 2016; ZACHARY, 2017).

Dogs predominantly feature asymptomatic or subclinical infections and few animals develop serious infections (SHUBITZ et al., 2005), of which the pulmonary form is considered the most common (GREENE, 2015). Occasionally, the disseminated form is observed, especially in immunosuppressed animals (BOSCO et al., 2016; CASWELL \& WILLIAMS, 2016). Human infection in semiarid 
Northeastern Brazil occurs as outbreaks or single cases and is often associated with hunting of wild animals (COSTA et al., 2001; CORDEIRO et al., 2009; TOGASHI et al., 2009). However, there is still little information on the clinical and pathologic characteristics of canine coccidioidomycosis in this area (WANKE et al., 1999). In this paper, we described a case of systemic Coccidioides sp. infection in a dog in the state of Paraiba, Northeastern Brazil.

\section{MATERIALS AND METHODS}

A dog with a history of cachexia, incoordination, and skin lesions died and was submitted to necropsy. Routine samples from all organs were collected, fixed in $10 \%$ neutral buffered formalin, routinely processed for histology, and stained with hematoxylin and eosin (HE). Histochemical techniques, including Grocott methenamine silver (GMS) and periodic acid-Schiff (PAS) staining, were used to reveal the agent and its morphological characteristics. To show the melanin pigment, special Fontana-Masson (FM) staining was used.

Sections of the cervical lymph node were processed for immunohistochemistry (IHC). IHC was performed on an automated stainer (Nemesis 3600, BioCare Medical, Concord, CA). A rabbit biotinylated anti-Coccidioides immitis polyclonal antibody (Gibson Bioscience, Lexyngton, KY) at a dilution of 1: 10,000 for 60 min was used to detect the target. The immunoreaction was visualized using 3,3-diaminobenzidine (DAB) substrate (BioCare Medical, Concord, CA) for $12 \mathrm{~min}$ contrasted with hematoxylin.

Sections of the skin were processed for IHC using polyclonal antibodies including CD3 $\left(\right.$ Dako Agilent ${ }^{\mathbb{R}}$ ), CD20 $\left(\right.$ Thermo $\left.^{\circledR}\right)$, Iba-1 $\left(\right.$ Wako $\left.^{\circledR}\right)$, Granzyme B (Spring ${ }^{\circledR}$ ) and monoclonal Tryptase (Dako Agilent $^{\circledR}$ ), CD45RA (Dr P.F. Moore, Davis, CA), CD45 (Dr P.F. Moore, Davis, CA) and MUM1 (Biocare medical ${ }^{\circledR}$ ) at the manufacturer's recommended dilutions. As amplification and detection system the Envision Dual Link (DAKO, K4065) and diaminobenzidine chromogen (DAKO, K3468) were used and counterstained were with Harris' Hematoxylin.

\section{RESULTS}

An adult, mixed breed, free-ranging male dog from the city of Patos (semiarid region of the state of Paraiba, Brazil) was examined after a 9-day history of cachexia, incoordination, and skin lesions. Physical examination revealed apathy, sternal recumbency, bilateral mucopurulent ocular secretion, dyspnea, pulmonary crepitation, onychogryphosis, erosive and nodular lesions on the skin of the left lateral thorax, ventral chest, elbow, and coxofemoral joint area, as well as increased volume and stiffness of the left tibiotarsal joint. The dog spontaneously died a few hours later and was submitted for necropsy.

Grossly, there were circular cutaneous ulcerations on the costal and ventral abdominal region. The subcutaneous tissues of the ventral cervical region, tail base, scrotum, and perianal area were expanded by firm yellow nodules. The superficial cervical lymph nodes were enlarged and firm, and had pale yellow, elevated areas on the cut surface. In the thorax were $600 \mathrm{mls}$ of serosanguinous fluid. Throughout the lungs there were numerous white firm nodules measuring between 2 and $8 \mathrm{~mm}$ in diameter (Figure 1A) interspersed with extensive white and firm masses adjacent to the bronchi (Figure 1B). The pericardial sac was expanded with yellow to brown fluid containing yellow strands of fibrin. The epicardial surface of the heart was expanded by a nodule measuring $3 \mathrm{~cm}$ in diameter that also infiltrated the myocardium (Figure 1C). Similar nodules were also observed in the intercostal musculature and left tibiotarsal joint. In the epididymis, a diffuse yellowwhite and irregular thickening circumferentially compressing the adjacent testicular parenchyma was found. The testicles were small and yellow, and presented a protruding nodule with $1 \mathrm{~cm}$ in diameter on the surface (Figure 1D).

The lesions were histologically characterized by pyogranulomatous pneumonia, bronchitis, myocarditis, lymphadenitis, myositis, arthritis and osteomyelitis of the left tibiotarsal joint, and epididymitis. Inflammatory infiltrates consisted of numerous neutrophils surrounded by epithelioid and foamy macrophages, multinucleate giant cells, and fewer lymphocytes and plasma cells. Extensive areas of fibrosis were found surrounding the pyogranulomas. Multiple fungal yeasts (spherules) with 15 to $80 \mu \mathrm{m}$ in diameter and a thick double hyaline wall were found freely within the neutrophilic infiltrates or in the cytoplasm of multinucleate giant cells. Spherules contained a basophilic center with homogeneous, granular, or flocculent material (immature spherules) or round endospores (mature spherules) with 6 to $8 \mu \mathrm{m}$ in diameter (Figure 2A). The spherules were stained with PAS (Figure 2A, inset) and GMS stain (Figure 2B). The organisms presented immunopositivity for Coccidioides spp. IHC (Figure 2C). In the lungs, multiple vessels were occluded by mural deposition of basophilic mineral. 


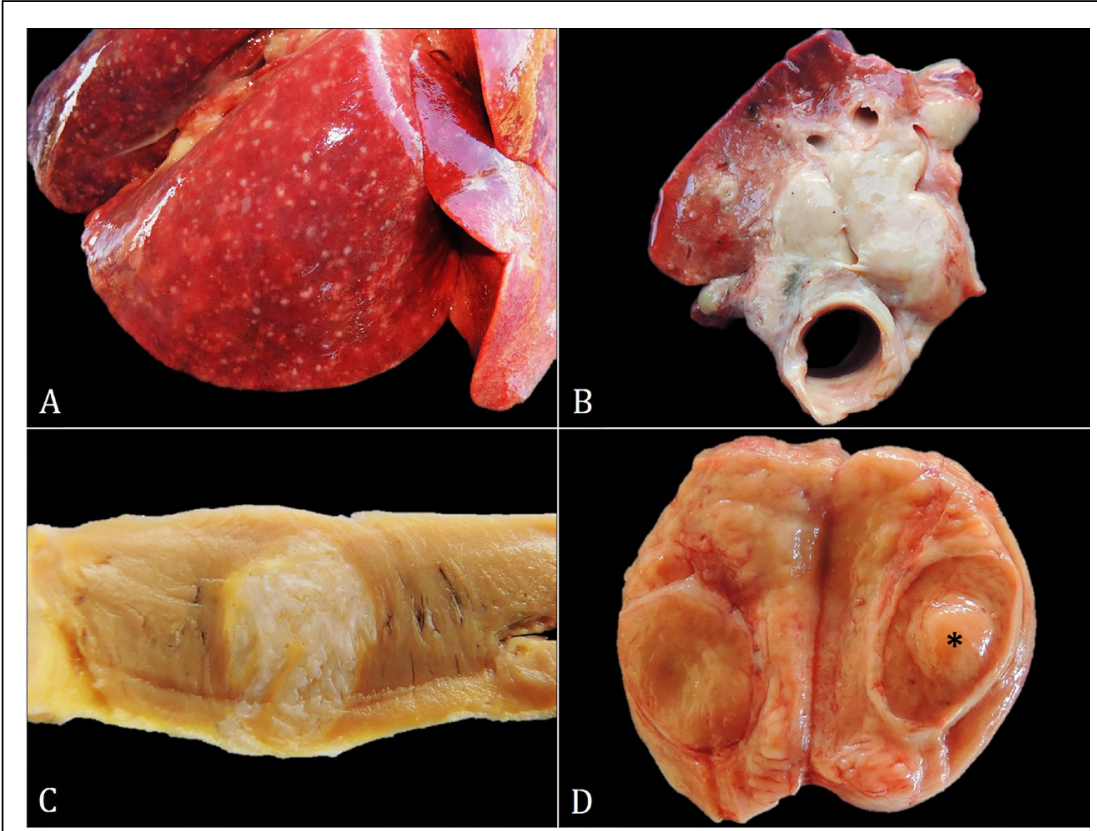

Figure 1 - Coccidioidomycosis in a dog. A) The lungs exhibit numerous yellow nodules throughout the parenchyma. B) Cut surface of the lung evidencing a white nodule partially surrounding the bronchi. C) Cut surface of the heart fixed with welldelimited and yellowish circular area in the myocardium. D) Epididymis with diffuse, yellow-white thickening surrounding the tunica albuginea. Testicle with parenchymal nodule (asterisk) consisting of the undifferentiated sarcoma area.

In addition to systemic fungal infection, tumor metastases were observed affecting the skin, lymph nodes, liver, and testicles. Histologically, there was densely cellular neoplastic proliferation, nonencapsulated, poorly delineated arranged in a loosely spaced layer, supported by sparse fibrovascular stroma. The cells were rounded with granular cytoplasm, varying in quantity from moderate to sparse and with evident boundaries. The nuclei were large, rounded with dotted chromatin and poorly evident nucleoli, sometimes with rimmed chromatin. There was discreet pleomorphism characterized by anisocytosis and anisokaryosis. Mitoses were frequent (4 to 5 per field of higher magnification [400x]). The neoplastic cells markedly infiltrated and expanded the superficial and deep dermis, lymphatic cords, hepatic sinusoids, and testicular parenchyma (Figure 2D).

All the antibodies used in IHC were negative for neoplastic cells and FM staining did not reveal the presence of pigment. Therefore, it was not possible to determine the cellular origin of the neoplasm and the diagnosis of undifferentiated sarcoma was established based on morphological analysis.

\section{DISCUSSION}

The diagnosis of coccidioidomycosis was made based on the histologic changes and confirmed by IHC. Although, $C$. immitis was thought to be the only Coccidioides sp. responsible for infection and clinical disease, additional molecular studies have revealed the existence of a new species, $C$. posadasii (FISHER et al., 2002). The species $C$. immitis occurs primarily in California and northwestern Mexico (FISHER et al., 2001), while the species C. posadasii is responsible for infections in other endemic regions, including in Brazil (BOSCO et al., 2016).

In Brazil, the disease has been frequently described in humans, especially in the semiarid region of the Northeast region (CORDEIRO et al., 2009). Sporadic cases of the infection have also been reported as affecting several species of domestic and wild animals (EULALIO et al., 2000; CORDEIRO et al., 2012; BOSCO et al., 2016). In canine species, coccidioidomycosis is an uncommon disease they are usually infected during armadillo hunting, where humans use the dogs to dig the soil and capture the

Ciência Rural, v.51, n.12, 2021. 


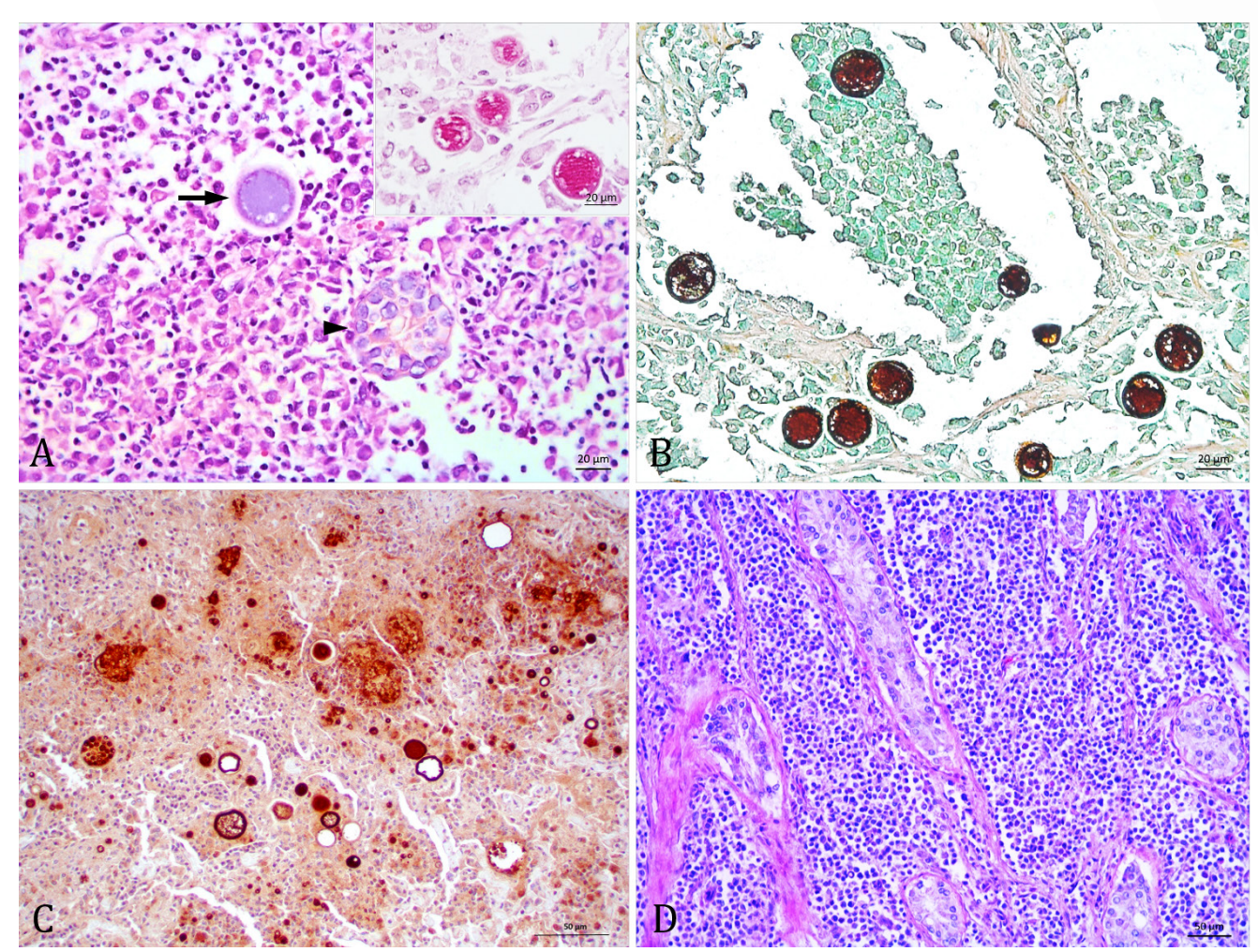

Figure 2 - Coccidioidomycosis in a dog. A) Cervical lymph node. Spherules of Coccidioides sp. at different stages of maturation. Immature spherule (left) with a nucleate, basophilic, homogeneous center (arrow) and mature spherule (right) containing endospores (arrowhead) surrounded by neutrophils, epithelioid macrophages, and lymphocytes [hematoxylin and eosin. Bar, $20 \mu \mathrm{m}$ ]. Inset, spherules stained with periodic acid-Schiff [Bar, $20 \mu \mathrm{m}]$. B) Tibiotarsal joint. Multiple spherules stained with Grocott methenamine silver [Bar, 20 $\mu \mathrm{m}]$. C) Cervical lymph node. Organisms are immunopositive for anti-Coccidioides immunohistochemistry [3,3-diaminobenzidine. Bar, $50 \mu \mathrm{m}]$. D) Testicle. Neoplastic cells infiltrating and markedly expanding the seminiferous tubules [hematoxylin and eosin. Bar, $50 \mu \mathrm{m}$ ].

animals (WANKE et al., 1999; BOSCO et al., 2016). In this case study, the means of infection remain undetermined, as the dog was a free-ranging animal.

The filamentous infective forms of Coccidioides spp. (arthroconidia) are found in the soil (GREENE, 2015). In endemic areas, infections usually occur due to secondary soil dust aerosolization by virtue of winds or heavy rain during dry periods (CASWELL \& WILLIAMS, 2016; SIMOES et al., 2016). Similarly, it is likely that exposure to arthroconidia occurred via contact with the environment.

The upper airways are the main port of entry in cases of coccidioidomycosis (ZACHARY, 2017). After inhalation and infection of the lungs, the arthroconidia become spherules that mature and produce endospores (GUARNER \& BRANDT,
2011). Cases of primary skin infection through direct implantation of organisms can also occur (PLOTNICK et al., 1997; CASWELL \& WILLIAMS, 2016; SIMOES et al., 2016). In the present case, the extensive lesions in the lung indicate a primary respiratory infection with hematogenous dissemination to other organs.

Absence of immunolabeling of neoplastic cells seen in this case, may be associated with a long period of fixation in formalin, harming antigenic recovery. Related factors as the temperature and length of fixation can result in reduced or lost immunoreactivity due to the occurrence of cross-links the fixation period, altering structures of proteins (RAMOS-VARA \& BEISSENHERZ, 2000). The concomitant occurrence of mycosis and neoplasms, as seen in this case, is rare. Only one report describes 
an association between coccidioidomycosis and lymphoma in a dog that was successfully treated using antibiotics, chemotherapy, and antifungal drugs (JEROSKI, 2003). The mineralization observed in the affected tissues in this case may be correlated with the chronic granulomatous inflammation associated with Coccidioides sp. has been previously described in pulmonary lesions (FERNANDEZ et al., 2018).

The differential diagnoses in our case included Rhinosporidium seeberi, which affects mucous membranes and exhibits larger sporangia, and are eventually confused with mature spherules of Coccidioides spp. due to the large size of the structures associated with endosporulation. The adiaspores of Emmonsia spp. are relatively larger, uninucleate with a thick capsule, and presents no endosporulation (CASWELL \& WILLIAMS, 2016). The yeasts of Paracoccidioides spp. can be confused with endospores of Coccidioides sp. when they do not have the typical multibudding aspect (QUEIROZTELLES \& ESCUISSATO, 2011). The diagnosis of coccidioidomycosis can be made through the morphological characteristics of the agent in the affected tissues (GUARNER \& BRANDT, 2011); however, the use of IHC and molecular techniques are essential for confirming the diagnosis (AJITHDOSS et al., 2011).

\section{CONCLUSION}

This case demonstrated that Coccidioides sp. can infect dogs that inhabit urban centers in the semiarid region of Northeastern Brazil likely due to exposure to dust from contaminated environments.

\section{ACKNOWLEDGEMENTS}

The authors are grateful to Coordenação de Aperfeiçoamento de Pessoal de Nível Superior (CAPES). The authors also thank the Department of Pathology, University of Georgia College of Veterinary Medicine for collaboration. Productivity scholarship of the Conselho Nacional de Desenvolvimento Científico e Tecnológico (CNPq), process number 309460/2017-4.

\section{DECLARATION OF CONFLICT OF INTEREST}

The authors declare no conflict of interest. The founding sponsors had no role in the design of the study; in the collection, analyses, or interpretation of data; in the writing of the manuscript, and in the decision to publish the results.

\section{AUTHORS' CONTRIBUTIONS}

All authors contributed equally for the conception and writing of the manuscript. All authors critically revised the manuscript and approved of the final version.

\section{REFERENCES}

AJITHDOSS, D. K. et al. Coccidioidomycosis presenting as a heart base mass in two dogs. Journal of Comparative Pathology, v.145, n.2-3, p.132-137, 2011. Available from: <https://doi. org/10.1016/j.jcpa.2010.12.014>. Accessed: Oct. 04, 2020. doi: 10.1016/j.jcpa.2010.12.014.

BOSCO, S. M. G. et al. Coccidioidomicose. In: MEGID, J. et al. (Eds). Doenças Infecciosas em Animais de Produção e de Companhia. Rio de Janeiro: Roca, 2016, p.869-877.

CASWELL, J. L.; WILLIAMS, K. J. Respiratory system. In: MAXIE, M. G. (Ed). Jubb, Kennedy, and Palmer's Pathology of Domestic Animals. vol.2, 6.ed. St. Louis: Elsevier, 2016. Cap.5, p.583-585.

CORDEIRO, R. A. et al. Serologic detection of coccidioidomycosis antibodies in northeast Brazil. Mycopathologia, v.167, n.4, p.187-190, 2009. Available from: <https://pubmed.ncbi.nlm.nih. gov/19116771/>. Accessed: Oct. 04, 2020. doi: 10.1007/s11046008-9173-5.

CORDEIRO, R. A. et al. Coccidioides posadasii infection in bats, Brazil. Emerging Infectious Diseases, v.18, n.4, p.668-670, 2012. Available from: <http://dx.doi.org/10.3201/eid1804.111641>. Accessed: Jan. 14, 2021. doi: 10.3201/eid1804.111641.

COSTA, F. A. M. et al. Pulmonary coccidioidomycosis in a armadillo hunter. Jornal de Pneumologia, v.27, n.5, p.275-278, 2001. Available from: $<$ https://www.scielo.br/scielo.php?script=sci_abstract\&pid $=$ S0 $10235862001000500009 \& n r m=i s o \& t \operatorname{lng}=p t>$. Accessed: Oct. 28, 2020. doi: 10.1590/S0102-35862001000500009.

FISHER, M. C. et al. Molecular and phenotype description of Coccidioides posadasii sp. nov., previously recognized as the nonCalifornian population of Coccidioides immitis. Mycologia, v.94, n.1, p.73-84, 2002. Available from: <https://spiral.imperial.ac.uk/ bitstream/10044/1/4213/1/Fisher_Cposadasii_Mycologia'02.pdf $>$. Accessed: Oct. 28, 2020. doi: 10. $2307 / 37618 \overline{4} 7$.

FISHER, M. C. et al. Biogeographic range expansion into South America by Coccidioides immitis mirrors new world patterns of human migration. Proceedings of the National Academy of Sciences of the United States of America, v.98, n.8, p.45584562, 2001. Available from: <https://europepmc.org/backend/ ptpmcrender.fcgi? accid $=$ PMC31873\&blobtype $=$ pdf $>$. Accessed: Oct. 04, 2020. doi: 10.1073/pnas.071406098.

FERNANDEZ, J. A. et al. Pathology of coccidioidomycosis in llamas and alpacas. Journal of Veterinary Diagnostic Investigation, v.30, n.4, p.560-564, 2018. Available from: $<$ https:// journals.sagepub.com/doi/pdf/10.1177/1040638718777282>. Accessed: Jan. 13, 2021. doi: 10.1177/1040638718777282.

GREENE, R. T. Coccidioidomicose e paracoccidioidomicose. In: GREENE, C.E. (Ed). Doenças Infecciosas em Cães e Gatos. 4.ed. Rio de Janeiro: Guanabara Koogan, 2015. Cap.60, p.1399-1413.

GUARNER, J.; BRANDT, M. E. Histopathologic diagnosis of fungal infections in the 21st century. Clinical Microbiology Reviews, v.24, n.2, p.247-280, 2011. Available from: <https:// www.ncbi.nlm.nih.gov/pmc/articles/PMC3122495/pdf/zcm247. pdf $>$. Accessed: Oct. 04, 2020. doi: 10.1128/CMR.00053-10.

JEROSKI, A. Multicentric lymphoma and disseminated coccidioidomycosis in a dog. Canadian Veterinay Journal, v.44, 
n.1, p.62-64, 2003. Available, from: <https://www.ncbi.nlm.nih. gov/pmc/articles/PMC340022/pdf/20030100s00027p62.pdf>. Accessed: Oct. 04, 2020.

LUNA-ISAAC, J. A. et al. Genetic analysis of the endemic fungal pathogens Coccidioides posadasii and Coccidioides immitis in Mexico. Medical Mycology, v.52, n.2, p.156-166, 2014. Available from: <https://pubmed.ncbi.nlm.nih.gov/24577001/>. Accessed: Oct. 28, 2020. doi: 10.1093/mmy/myt005.

PLOTNICK, A. N. et al. Primary cutaneous coccidioidomycosis and subsequent drug eruption to itraconazole in a dog. Journal of the American Animal Hospital Association, v.33, n.2, p.139-143, 1997. Available from: <https://doi.org/10.5326/15473317-33-2139>. Accessed: Oct. 04, 2020. doi: 10.5326/15473317-33-2-139.

QUEIROZ-TELLES, F.; ESCUISSATO, D. L. Pulmonary paracoccidioidomycosis. Seminars in Respiratory and Critical Care Medicine, v.32, n.6, p.1-11, 2011. Available from: <http:// dx.doi.org/10.1055/s-0031-1295724>. Accessed: Jan. 14, 2021. doi: $10.1055 / \mathrm{s}-0031-1295724$

RAMOS-VARA, J. A.; BEISSENHERZ, M. E. Optimization of immunohistochemical methods using two different antigen retrieval methods on formalin-fixed, paraffin-embedded tissues: experience with 63 markers. Journal of Veterinary Diagnostic Investigation, v.12, n.4, p.307-311, 2000. Available from: $<$ https://journals.sagepub.com/doi/pdf/10. 1177/104063870001200402>. Accessed: Mar. 29, 2021. doi: $10.1177 / 104063870001200402$.
SHUBITZ, L. E. et al. Incidence of Coccidioides infection among dogs residing in a region in which the organism is endemic. Journal of the American Veterinary Medical Association, v.226, n.11, p.1846-1850, 2005. Available from: <https://doi. org/10.2460/javma.2005.226.1846>. Accessed: Oct. 04, 2020. doi: 10.2460/javma.2005.226.1846.

SIMOES, D. M. et al. Retrospective analysis of cutaneous lesions in 23 canine and 17 feline cases of coccidioidomycosis seen in Arizona, USA (2009-2015). Veterinay Dermtology, v.27, n.5, p.1-10, 2016. Available from: <http://www.tokyovetsallergy.com/ fa2016101.pdf $>$. Accessed: Oct. 04, 2020. doi: 10.1111/vde.12356.

TOGASHI, R. H. et al. Coccidioidomicose pulmonar e extrapulmonar: três casos em zona endêmica no interior do Ceará. Jornal Brasileiro de Pneumologia, v.35, n.3, p.275-79, 2009. Available from: $<$ https://www.scielo.br/scielo.php?script=sci_artt ext\&pid=S1806-37132009000300013>. Accessed: Oct. 04, 2020. doi: 10.1590/S1806-37132009000300013.

WANKE, B. et al. Investigation of an outbreak of endemics coccidioidomicose in Brazil's northeastern state of Piaui with a review of the occurrence and distribution of Coccidioides immitis in three other Brazilian states. Mycopathologia, v.148, n.2, p.57-67, 1999. Available from: <https://pubmed.ncbi.nlm.nih.gov/11220226/>. Accessed: Oct. 28, 2020. doi: 10.1023/a:1007183022761.

ZACHARY, J. F. Mechanisms of microbial infections. In: ZACHARY, J. F. (Ed). Pathologic Basis of Veterinary Disease. 6.ed. St. Louis: Elsevier, 2017. Cap.4, p.231-234. 